Paedagogia Christiana

I/29 (2012) - ISSN I505-6872

Stanisław Cierkowski*

Toruń

\title{
Wychowanie w rodzinie czy przez państwo? Rozważania teoretyczno-prawne
}

\section{Wstęp}

Wychowanie - rodzina - państwo to triada pojęć, które w nowożytnej historii Europy i jeszcze bardziej we współczesnym świecie wywołują wiele emocji i napięć społecznych ${ }^{1}$. W związku z tym pozostaje wciąż aktualne pytanie: kto ma wychowywać zarówno małe dziecko, jak i dorastającego

* Ks. dr Stanisław Cierkowski jest wykładowcą na Wydziale Nauk Pedagogicznych oraz Wydziale Teologicznym Uniwersytetu Mikołaja Kopernika w Toruniu.

1 Jedne $\mathrm{z}$ ostatnich napięć społecznych w Polsce, jakie zostały wywołane we wspomnianej dziedzinie, dotyczyły ustawowego obniżenia z siedmiu do sześciu lat wieku dzieci, które - zgodnie z nowelizacją ustawy o systemie oświaty - miały rozpocząć pierwszy rok nauki w szkole podstawowej od dnia 1 września 2012 roku. Konsekwencją tego będzie także obowiązek odbycia przez dzieci pięcioletnie rocznego przygotowania przedszkolnego w przedszkolu, oddziale przedszkolnym zorganizowanym w szkole podstawowej lub w innej formie przygotowania przedszkolnego. Zob. art. 9, 10, 12, 14 ustawy z dnia 19 marca 2009 r. o zmianie ustawy o systemie oświaty oraz o zmianie niektórych innych ustaw, Dz.U. 2009, nr 56, poz. 458. W wyniku protestów rodziców, którzy twierdzą, że miejsce sześciolatka, a tym bardziej pięciolatka, jest w rodzinie, nie zaś w szkole czy w przedszkolu, zwłaszcza w oddziale przedszkolnym zorganizowanym w szkole podstawowej, a także na skutek niedostatecznego przygotowania szkół do przyjęcia sześciolatków, rząd Rzeczypospolitej Polskiej zapowiedział odroczenie obowiązku szkolnego dla sześciolatków do 1 września 2013 roku, po uprzedniej powtórnej nowelizacji ustawy o systemie oświaty przez nowo ukonstytuowany parlament. Zob. http:// wiadomosci.wp.pl/kat,1342,title,Szesciolatki-w-szkole-za-rok-premier-przesuwa-termin,wid, 138525 22, wiadomosc.html?ticaid=1d3c3, dnia 20.10.2011 r.; http://pawelsikora.wordpress. 
młodego człowieka, to znaczy czy jego własna rodzina, w której przyszedł na świat, czy może państwo, które jako byt społeczny tworzy w tym celu specjalne instytucje i określa dla nich odpowiednie programy edukacyjnowychowawcze ${ }^{2}$. Poza tym, na bazie wrodzonego każdemu poczucia sprawiedliwości i słuszności, można i należy pytać o właściwe proporcje udziału rodziny i państwa w procesie wychowania, gdyż - jak powszechnie wiadomo - współczesna rodzina nie zawsze jest w stanie sprostać wszystkim zadaniom edukacyjno-wychowawczym, zwłaszcza związanym z edukacją szkolną. Zatem podstawowym pytaniem, które domaga się odpowiedzi, jest pytanie o środowisko wychowania osoby i o podmioty, które są odpowiedzialne za dołożenie należytej staranności, aby proces ten się powiódł. Drugorzędną kwestią jest rozwiązanie problemu właściwych proporcji oddziaływania rodziny i państwa w procesie wychowawczym. Chcąc zatem znaleźć odpowiedź na wspomniane pytania, zajmiemy się najpierw naturą wychowania, bliżej określając semantyczną treść pojęcia „wychowanie”. Następnie zanalizujemy wychowanie w rodzinie, które w większości kultur i społeczeństw jest naturalnym biegiem rzeczy. W końcu podejmiemy refleksję nad zadaniami państwa w procesie wychowawczym.

\section{Semantyczna treść pojęcia wychowanie}

Powszechnie używany termin ,wychowanie” pod względem prawnym należy do tak zwanych pojęć nieostrych, zwanych niedookreślonymi ${ }^{3}$. Oznacza to, że polski ustawodawca w żadnym akcie prawnym należącym do polskiego systemu prawnego nie dookreśla semantycznej treści tegoż pojęcia. W konsekwencji w aktach prawnych, które w sposób przedmiotowy regulują bardzo szeroki zakres spraw dotyczących wychowania, nie odnajdujemy ustawowej definicji pojęcia „wychowanie”. Co więcej, luka ta najprawdopodobniej nie jest przypadkowa, lecz zamierzona przez polskiego ustawodawcę, gdyż proces wychowania osoby ludzkiej zazwyczaj jest bardzo długi

com/2011/03/16/o-zmianie-ustawy-o-zmianie-ustawy-czyli-jak-reformuje-sie-system-oswiaty/, dnia 20.10.2011 r.

${ }^{2}$ Skutkiem aktualnie obserwowanego procesu globalizacji jest zjawisko narastającej współpracy państw. Na kontynencie europejskim współpraca ta przybrała organizacyjną formę Unii Europejskiej. Unia za pomocą dyrektyw oddziałuje na życie polityczne, gospodarcze i społeczne państw członkowskich. Por. J. Helios, W. Jedlicka, Rola procedur UE w zwiazku z integracja, w: J. Stelmach (red.), Filozofia prawa wobec globalizmu, Kraków 2003, s. 75-76. Możliwe jest zatem oddziaływanie Unii Europejskiej na zadania państwa członkowskiego w procesie edukacyjno-wychowawczym.

3 Zob. L. Morawski, Zasady wykładni prawa, Toruń 2006, s. 243-244. 
i przebiega w sposób niezwykle skomplikowany. Nie jest zatem możliwe objęcie tegoż pojęcia jedną i niebudzącą wątpliwości definicją legalną. Z drugiej strony, nieostre pojęcie ,wychowanie” domaga się jednak doprecyzowania, i to nie tylko dla celów akademickich i sądowych, ale przede wszystkim dla praktyki pedagogicznej, która pragnie w sposób świadomy, zaplanowany i metodyczny ${ }^{4}$ tak oddziaływać na młodego człowieka, aby go ukształtować w sposób integralny na dojrzałą osobę ludzką, zdolną do wkroczenia we wszystkie napotkane relacje interpersonalno-społeczne życia dorosłego i do dojrzałego w nich funkcjonowania (por. DWCH 1)

Z powyżej wskazanych powodów warto przytoczyć niektóre określenia pojęcia „wychowanie”, które ten termin dookreślają i jednocześnie wypełniają. Warto też zaznaczyć, iż wszelkie próby bardziej szczegółowego określenia tegoż pojęcia mniej lub bardziej uwypuklają niektóre aspekty wychowania, w zależności od konkretnej profesjonalnej perspektywy, z jakiej dany autor dokonuje wspomnianej interpretacji semantycznej. Poza tym, warto także usystematyzować wspomniane określenia według kryterium ogólności i szczegółowości, przytaczając najpierw definicje oparte na przesłankach filozoficzno-teologicznych, które akcentują bardziej ogólny sens i cel wychowania, kończąc natomiast na określeniach psychologiczno-pedagogicznych, które szczegółowo formułują metody i środki wychowawcze. Powyżej przyjęta systematyka pomoże nam dookreślić pojęcie „wychowanie”, zwłaszcza z perspektywy filozoficzno-teologicznej i psychologiczno-pedagogicznej, aby lepiej poznać jego najbardziej integralną treść.

Jeśli chodzi o perspektywę filozoficzno-teologiczną, to hiszpański prof. Augusto Sarmiento, bazując na przesłankach przytoczonych przez św. Tomasza z Akwinu i wypowiadając się w sposób deskryptywny o wychowaniu, stwierdza:

ponieważ byt ludzki nie rodzi się skończony - aby żyć i dochodzić do pełni, do której jako osoba jest powołany, wymaga, by się o niego troszczyć od pierwszej chwili jego egzystencji. Osobowa godność zrodzonego dziecka wymaga, by pomagać mu w odpowiedni sposób. Wychowanie jest przeto pomaganiem za pomocą stosownych środków we wzroście i rozwoju dziecka ku doskonałości,

${ }^{4}$ Zob. Z. Kwieciński, Składniki i aspekty edukacji. Potrzeba całościowego ujęcia, w: H. Muszyński (red.), Socjalizacja - osobowość - wychowanie, Poznań 1989, s. 48.

${ }^{5}$ Zob. Sobór Watykański II, Deklaracja o wychowaniu chrześcijańskim Gravissimum educationis, w: Sobór Watykański II, Konstytucje, dekrety, deklaracje, Poznań 1986 - w tekście DWCH z odnośnym numerem. 
gdyż odpowiada ono jego ludzkiej naturze, tak na poziomie ciała, jak i na poziomie ducha ${ }^{6}$.

$\mathrm{W}$ perspektywie filozoficzno-teologicznej $\mathrm{u}$ podstaw procesu wychowania osoby leży zatem pojęcie wrodzonej i zarazem niezbywalnej godności ludzkiej, która w dzisiejszym świecie została bardzo mocno zaakcentowana zarówno przez nauczanie papieskie, jak również przez dwudziestowieczny proces kodyfikacji ochrony praw człowieka7. Godność ta domaga się, aby osoba ludzka rozwijała się w sposób harmonijny i integralny od samego urodzenia, zmierzając w ten sposób do spełnienia swego człowieczeństwa ${ }^{8}$. Odpowiedzią na ten naturalny wymóg rozwoju psychosomatycznego człowieka jest wychowanie, które pełni niejako funkcję pomocniczą w relacji do osobowego rozwoju każdej istoty ludzkiej.

Papież Jan Paweł II, pogłębiając ten kierunek rozumowania i opierając się równocześnie na fundamencie wymogów prawa naturalnego, którego w ujęciu chrześcijańskim - ostatecznym autorem i prawodawcą jest Bóg9 bardziej szczegółowo dookreśla proces wychowania. Jednakże zauważa on także, że wychowanie nie jest procesem jednostronnym, choć niewątpliwie ukierunkowanym na dobro dziecka jako wychowanka. Proces ten wyciska osobowe piętno także na wychowawcach, którymi - w naturalnym biegu rzeczy - są rodzice. W tym duchu Jan Paweł II konstatuje: „Wychowanie jest [...] przede wszystkim obdarzaniem człowieczeństwem - obdarzaniem dwustronnym. Rodzice obdarzają swym dojrzałym człowieczeństwem nowo narodzonego człowieka, a ten z kolei obdarza ich całą nowością i świeżością człowieczeństwa, które z sobą przynosi na świat" (LdR 16) ${ }^{10}$. Moralista ks. prof. Marian Pokrywka, rozważając temat wychowania i podążając w tym względzie za myślą Jana Pawła II, konstatuje: „Proces wychowania jest zróżnicowanym i złożonym fenomenem. I choć najczęściej kojarzony jest z okresem dzieciństwa i młodości, to jednak jest trwającą przez całe życie sztuką «tworzenia człowieka» i obejmuje wszystkie sfery i wymiary ludzkiej egzystencji" "'. Zatem można skonstatować, że dziecko obdarzone

${ }^{6}$ A. Sarmiento, Małżeństwo chrześcijańskie. Podręcznik teologii małzeństwa i rodziny, Kraków 2002, s. 403.

7 Zob. S. Jasionek, Prawa człowieka, Kraków 2005, s. 13.

${ }^{8}$ Zob. tamże, s. 42.

9 Zob. R. Pizzorni, Diritto naturalne e diritto positivo in S. Tommaso d'Aquino, Bologna 1999, s. 54.

10 Jan Paweł II, List do Rodzin, Poznań 1994 - w tekście LdR z odnośnym numerem.

${ }^{11}$ M. Pokrywka, Antropologiczne podstawy wychowania w rodzinie, w: K. Jeżyna, T. Zadykowicz (red.), Wychowanie w rodzinie chrześcijańskiej. Przestanie moralne Kościoła, Lublin 2008, s. 13. 
przyrodzoną i niezbywalną godnością ludzką w procesie wychowania ulega zjawisku humanizacji12, czyli innymi słowy staje się w pełni człowiekiem w perspektywie społeczno-kulturowej. Niezwykle trafną rekapitulacją takiego ujęcia procesu wychowania z perspektywy filozoficzno-teologicznej są słowa ks. prof. Józefa Majki: ,Wychowanie w swojej istocie jest niczym innym, jak kształtowaniem człowieka i to nie w sensie rozwoju człowieka jako gatunku, lecz w znaczeniu doskonalenia każdego indywidualnego człowieka we wszystkich dziedzinach jego życia i działalności, czyli kształtowaniem osoby ludzkiej"'13.

Na bazie wspomnianego ujęcia trzeba pytać o bardziej szczegółowe wskazówki dotyczące procesu wychowania. Odnajdujemy je w próbach określenia treści pojęcia „,wychowanie” od strony psychologiczno-pedagogicznej. Z samej tylko perspektywy psychologicznej wychowanie zostało określone przez uczonych Arthura Reber i Emily Reber jako: „zbiorowy wpływ wszelkich czynników środowiskowych, które oddziałują na rozwój i zachowanie"14. Natomiast z perspektywy pedagogicznej wychowanie jest rozumiane przez prof. Mariana Śnieżyńskiego jako: „całokształt sposobów i procesów pomagających istocie ludzkiej, zwłaszcza przez interakcję, urzeczywistnić swoje człowieczeństwo" ${ }^{15}$. Podążając tym samym tokiem myślenia, ks. prof. Adam Skreczko precyzuje, że wychowanie to: „świadomie organizowana działalność społeczna, oparta na stosunku wychowawczym między wychowankiem a wychowawcą, której celem jest wywołanie zamierzonych zmian w osobowości wychowanka. Zmiany te obejmują zarówno stronę poznawczo-instrumentalną, jak też emocjonalno-motywacyjną"16. Zatem wychowanie, w szczególności rozumiane jako działalność intencjonalna, ma na celu ukształtowanie wszystkich sfer osobowościowych istoty ludzkiej.

Najpełniejsze jednak określenie treści pojęcia ,wychowanie” w perspektywie psychologiczno-pedagogicznej można odnaleźć u prof. Krystyny Ostrowskiej, która proponuje następujące jego rozumienie:

12 Zob. L. Melina, Natura e famiglia: un nesso da esplorare, w: tenże (red.), Il criterio della natura e il futuro della famiglia, Siena-Roma 2010, s. 11.

13 J. Majka, Wychowanie personalistyczne wychowaniem chrześcijańskim, w: F. Adamski (red.), Wychowanie w rodzinie, Kraków 2010, s. 15.

${ }^{14}$ A. S. Reber, E. S. Reber, Wychowanie, w: A. S. Reber, E. S. Reber, Stownik psychologii, Warszawa 2008, s. 883. Nota bene autorzy explicite przeciwstawiają wychowanie naturze. Por. tamże, s. 442, 883.

${ }^{15}$ M. Śnieżyński, Wychowanie, w: Jan Paweł II, Encyklopedia nauczania społecznego, oprac. A. Zwoliński, Radom 2005, s. 588.

${ }^{16}$ A. Skreczko, Wychowanie. Natura i cel, w: E. Ozorowski (red.), Stownik Matżeństwa $i$ Rodziny, Warszawa-Łomianki 1999, s. 474-475. 
Wychowanie jest procesem społecznym, w którym uczestniczą wychowawca i wychowanek. Jego celem jest obudzenie w wychowanku procesu samowychowania, zmierzającego do wzrastania w człowieczeństwie. Należy podkreślić, że wychowanie ma miejsce tylko wtedy, kiedy jest działalnością świadomą, celową i interpersonalną. Na wychowanie jako działanie intencjonalne mogą oddziaływać różne wpływy o charakterze przypadkowym (np. wpływy ulicy czy podwórka). Wychowanie jest procesem, w którym wyróżnia się wychowanka jako podstawową przyczynę osobową wychowania, wychowawcę jako pomocniczą przyczynę osobową wychowania oraz sytuację ${ }^{17}$.

Można zatem, naszym zdaniem, skonstatować, że stosunek wychowawczy jest stosunkiem dwustronnym o charakterze interakcyjnym. Zachodzi on pomiędzy wychowawcą a wychowankiem, przy czym podstawową przyczyną osobową wychowania jest dziecko-wychowanek i jego osobowe dobro. Z tej racji wychowanie jest procesem kształtowania człowieczeństwa osoby ludzkiej, rozumianym jako formowanie i doskonalenie jej integralnej i zdrowej osobowości.

\section{Rodzina jako środowisko wychowawcze}

Powszechnie uznaje się, że rodzina jest najstarszą grupą społeczną ${ }^{18}$, wyprzedzając pod względem swego istnienia wszelkie inne grupy stowarzyszeniowe, włącznie z państwem. Rodzina pojawiła się spontanicznie już wtedy, gdy pojawili się ludzie ${ }^{19}$. Zatem przez bardzo długi czas prehistorii, to znaczy aż do momentu powstania państwa, a także we wczesnym jego rozwoju cywilizacyjnym, rodzina była jedynym środowiskiem wychowawczym. Z tej perspektywy możemy z pewnością określić rodzinę jako pierwotne środowisko wychowawcze, gdyż już od początku swego istnienia rodzina przeżywała swój wewnętrzny rozwój poprzez rodzenie i socjalizację potomstwa, której poziom odpowiadał etapowi cywilizacyjnemu rodziny. Jednakże należy pamiętać, że kryterium temporalne nie jest jedyną racją, która przemawia za uznaniem pierwszoplanowej roli rodziny w dziedzinie wychowania. Drugą racją w omawianej problematyce, jeszcze bardziej niż pierwsza przemawiającą do ludzkiego rozumu, jest kryterium natury. Istnie-

${ }_{17}$ K. Ostrowska, Wychowanie, w: tenże (red.), Wychowanie do życia $w$ rodzinie. Słownik pojęć, Kraków 2004, s. 123.

18 Zob. T. Smyczyński, Prawo rodzinne i opiekuńcze, Warszawa 2009, s. 1.

19 Zob. G. Bonilini, Manuale di diritto di famiglia, Torino 2010, s. 1. 
nie i konstytucja rodziny jest bowiem wynikiem prawa naturalnego ${ }^{20}$, gdyż jest fenomenem uniwersalnym, pojawiającym się w każdym społeczeństwie i na każdym jego etapie rozwoju ${ }^{21}$. Z tego punku widzenia rodzina, posiadając umocowanie prawno-naturalne, nie traci swoich najbardziej pierwotnych zadań w dziedzinie wychowania, lecz zachowuje je zarówno w momencie powstania państwa, jak i w czasie każdego etapu jego rozwoju cywilizacyjnego. Niezmienne prawo natury, jak powszechnie wiadomo, nie daje się bowiem derogować ani przez jakiegokolwiek suwerena, ani przez instytucje jemu podległe ${ }^{22}$. Zatem na bazie prawa natury rodzina zarówno na niskim, jak i na wysokim etapie rozwoju cywilizacyjno-kulturowego niezmienne pozostaje środowiskiem wychowawczym, które posiada legitymację prawa natury do wychowania własnego potomstwa. Warto dodać, że w tym naturalnym procesie uczestniczą zarówno rodzice jako pierwotni wychowawcy swojego potomstwa, jak i dzieci jako wychowankowie swoich rodziców, które przychodzą na świat pozbawione wymiaru społeczno-kulturowego. Stąd: „W rodzinie [...] natura ulega humanizacji i odnajduje swoją formę ludzką" $\mathrm{Z}$ tej perspektywy nie jest obojętne, że państwo w niektórych przypadkach chciałoby obligatoryjnie nadać jakiś istotny co do ciężaru gatunkowego rys w wychowaniu młodego człowieka wbrew jego rodzicom jako pierwotnym wychowawcom, mającym w tym względzie wyraźny mandat prawa natury w zakresie wychowania swojego potomstwa (DWCH 3). Rodzice bowiem, jak powszechnie wiadomo, nie wychowują swoich dzieci w sposób neutralny w relacji do wyznawanych przez siebie poglądów i przekonań, zwłaszcza w sferze moralnej i religijnej. Wręcz przeciwnie, rodzice - powiązani ze swoimi dziećmi głębokimi więzami emocjonalno-ekspresyjnymi i chcący ich dobra - pragną nadać wychowaniu swoich dzieci taką formę społeczną, kulturową, moralną i religijną, która odpowiada ich własnym przekonaniom. Stąd państwo, niemające od początku swego istnienia legitymacji prawnonaturalnej do wychowania dzieci, nie może narzucać rodzicom swojej wizji wychowania młodego człowieka, zwłaszcza gdy byłaby ona oderwana od określonej aksjologicznie koncepcji wychowawczej rodziców.

${ }^{20} \mathrm{Z}$ racji swojej konstytucji prawno-naturalnej rodzina jest wprost nazywana „wspólnotą naturalną". Zob. J. J. Pérez-Soba, La famiglia, prima fonte del futuro della societá, w: L. Melina (red.), dz. cyt., s. 31.

${ }^{21}$ Zob. L. Melina, dz. cyt., s. 9.

${ }_{22}$ Zob. W. Gromski, Prawo natury, w: U. Kalina-Prasznic (red.), Encyklopedia prawa, Warszawa 2007, s. 617. Obszerniej na temat relacji prawa naturalnego z państwowym prawem pozytywnym zob. T. Ślipko, Problem stabilności prawa naturalnego, w: M. Szyszkowska (red.), Powrót do prawa ponadustawowego, Warszawa 1999, s. 101-104.

${ }^{23}$ L. Melina, dz. cyt., s. 11. 
Pomimo że określenie zarówno źródeł, jak i norm prawa naturalnego nie jest łatwe, to jednak poczynione przez nas wnioski zostały bezspornie potwierdzone przez dyspozycje norm prawa pozytywnego, i to zarówno w prawie międzynarodowym, jak i w wewnętrznym prawie polskim. Pierwszy porządek w perspektywie formalno-prawnej ochrony praw człowieka w pełni szanuje legitymację prawno-naturalną rodziców do wychowania swoich dzieci. Formalnie po raz pierwszy państwa, zgromadzone w ONZ, wypowiedziały się w tym duchu w Powszechnej Deklaracji Praw Człowieka z dnia 10 grudnia 1948 roku. W art. 16 ust. 3 Deklaracja ta potwierdza: „Rodzina jest naturalną i podstawową komórką społeczeństwa oraz jest uprawniona do ochrony ze strony społeczeństwa i Państwa"24. W konsekwencji art. 26 tej Deklaracji dodaje: „Rodzice korzystają z prawa pierwszeństwa, jeśli chodzi o wybór wykształcenia dla swoich dzieci”25. Należy dodać, że choć Powszechna Deklaracja Praw Człowieka była bardzo ogólna i nie miała charakteru wiążącego, to jednak po raz pierwszy wyznaczyła wspólne standardy dla wszystkich narodów i państw ${ }^{26}$ między innymi w dziedzinie naturalnoprawnych relacji pomiędzy rodzicami a dziećmi, a także w zakresie poszanowania podstawowych praw rodziców wobec ich dzieci ze strony państw zgromadzonych w ONZ.

Wartość normatywna postanowień Powszechnej Deklaracji Praw Człowieka $\mathrm{w}$ zakresie praw rodziny i wychowania w rodzinie została bardzo mocno wzmocniona przez traktaty z zakresu praw człowieka, przyjęte zarówno $\mathrm{w}$ systemie uniwersalnym, jak $\mathrm{i}$ w systemach regionalnych: europejskim, amerykańskim i afrykańskim. W tym zakresie uniwersalny system ochrony praw człowieka reprezentowały prawnie wiążące Międzynarodowe Pakty Praw Człowieka z dnia 16 grudnia 1966 roku, które potwierdzały i uszczegóławiały chroniony zakres praw rodziny, w tym prawno-naturalny charakter relacji rodzice-dzieci i prawo rodziców do wychowania swych dzieci zgodnie z własnymi przekonaniami moralnymi i religijnymi. W tej materii Międzynarodowy Pakt Praw Obywatelskich i Politycznych w art. 18 postanawia: „Państwa-Strony niniejszego Paktu zobowiązują się do poszanowania wolności rodziców lub - w odpowiednich przypadkach - opiekunów prawnych, w zakresie zapewnienia swym dzieciom wychowania religijnego i moralne-

${ }^{24}$ Prawa rodziny - prawa $w$ rodzinie $w$ świetle standardów międzynarodowych. Zbiór dokumentów, tłum. i oprac. T. Jasudowicz, Toruń 1999, s. 32.

25 Tamże.

${ }^{26}$ M. N. Shaw sugeruje, że Powszechna Deklaracja Praw Człowieka stała się dokumentem prawnie wiążącym na mocy zwyczaju, ogólnych zasad prawa międzynarodowego, interpretacji Karty Narodów Zjednoczonych i późniejszej praktyki, zwłaszcza że odcisnęła ona swoje piętno na prawie traktatowym praw człowieka i na konstytucjach wielu państw. Zob. M. N. Shaw, Prawo międzynarodowe, Warszawa 2006, s. 184. 
go zgodnie z własnymi przekonaniami"27. Podobnie Międzynarodowy Pakt Praw Gospodarczych, Socjalnych i Kulturalnych w art. 13 potwierdza, że:

Państwa-Strony niniejszego Paktu zobowiązują się do poszanowania wolności rodziców lub - w odpowiednich przypadkach - opiekunów prawnych, w zakresie wyboru dla swych dzieci szkół innych niż szkoły założone przez władze publiczne, ale odpowiadających minimalnym wymaganiom w zakresie nauczania, jakie mogą być ustalone lub zatwierdzone przez państwo, jak również w zakresie zapewnienia swym dzieciom wychowania religijnego i moralnego zgodnie z własnymi przekonaniami ${ }^{28}$.

Dla podkreślenia terytorialnego obowiązywania tych norm warto dodać, że obecnie dyspozycjami Międzynarodowego Paktu Praw Obywatelskich i Politycznych jest związanych 165 państw, a normami Międzynarodowego Paktu Praw Gospodarczych, Socjalnych i Kulturalnych 160 państw ${ }^{29}$. Oznacza to, że prawno-naturalny charakter zarówno samej rodziny, jak i procesu wychowania został powszechnie uznany w prawie międzynarodowym ochrony praw człowieka.

Ten prawno-naturalny charakter relacji rodzice-dzieci został jeszcze dobitniej potwierdzony w międzynarodowych dokumentach ochrony praw człowieka, które gwarantują podstawowe i niezbywalne prawa dziecka. W tym zakresie Deklaracja Praw Dziecka z dnia 20 listopada 1959 roku w art. 6 stwierdza bardzo dobitnie: „Dziecko potrzebuje miłości i zrozumienia dla pełnego i harmonijnego rozwoju swej osobowości. Tam, gdzie to tylko możliwe, winno ono wzrastać pod pieczą i odpowiedzialnością swoich rodziców, a w każdym bądź razie w atmosferze miłości oraz bezpieczeństwa moralnego i materialnego; poza wyjątkowymi okolicznościami, małoletnie dziecko nie powinno być odłączone od swej matki" ${ }^{30}$. Widać zatem wyraźnie, iż państwa, które podpisały tę Deklarację, uznały prymat rodziny w wychowaniu dzieci, przyznając że proces harmonijnego kształtowania osobowości dziecka, który jest integralnym elementem procesu wychowania, najlepiej przebiega w rodzinie. Rodzina bowiem jest zazwyczaj kolebką i siedliskiem więzów wzajemnej miłości, co wydatnie przyczynia się do wzbudzenia w dziecku poczucia bezpieczeństwa, i to zarówno od strony moralnej, jak

${ }^{27}$ Prawa rodziny - prawa $w$ rodzinie, s. 35.

28 Tamże, s. 46-47.

${ }^{29}$ Zob. M. Lubiszewski, Kodyfikacja ochrony praw człowieka w systemie uniwersalnym, w: B. Gronowska, T. Jasudowicz, M. Balcerzak, M. Lubiszewski, R. Mizerski, Prawa człowieka i ich ochrona, Toruń 2010, s. 62.

${ }^{30}$ Prawa rodziny - prawa $w$ rodzinie, s. 55. 
i materialnej ${ }^{31}$. Deklaracja Praw Dziecka nie miała charakteru prawnie-wiążącego, jednak była manifestacją woli państw co do poszanowania przyjętych w niej standardów, a także co do dążenia ku nim w przyszłości.

$\mathrm{Na}$ bazie standardów, zawartych w Deklaracji Praw Dziecka, dnia 20 listopada 1989 roku przyjęto już w pełni wiążącą Konwencję Praw Dziecka. W preambule tej Konwencji zapisano:

Państwa-Strony niniejszej Konwencji [...] przeświadczone, iż rodzina jako podstawowa komórka społeczna oraz naturalne środowisko rozwoju i dobrobytu wszelkich jej członków, a w szczególności dzieci, powinna być otoczona niezbędną ochroną i opieką, aby mogła w pełnym zakresie odgrywać swoją rolę w społeczeństwie; uznając, że dziecko dla pełnego i harmonijnego rozwoju swojej osobowości powinno wychowywać się w środowisku rodzinnym, w atmosferze szczęścia, miłości i zrozumienia ${ }^{32}$.

Rodzina zatem na podstawie przesłanek prawno-naturalnych została uznana $\mathrm{w}$ pozytywnym prawie międzynarodowym ochrony praw człowieka jako naturalne środowisko rozwoju i dobrobytu wszelkich jej członków, a w szczególności dzieci. Stąd w art. 5 tej Konwencji zamieszczono normę, iż:

Państwa-Strony będą szanować odpowiedzialność, prawa i obowiązki rodziców lub - w odpowiednich przypadkach - członków dalszej rodziny lub wspólnoty, zgodnie z obyczajami miejscowymi, opiekunów bądź innych osób prawnie odpowiedzialnych za dziecko, w zakresie zapewnienia mu - w sposób odpowiadający rozwojowi jego zdolności - możliwości ukierunkowywania go i udzielania mu właściwych rad przy korzystaniu z praw zapewnionych mu w niniejszej Konwencji ${ }^{33}$.

Ponadto państwa, będące Stronami Konwencji Praw Dziecka, uznały, że proces wychowania zasadniczo przebiega $\mathrm{w}$ rodzinie, a gwarancją realizacji tego postanowienia jest zakaz arbitralnego odłączania dzieci od ich rodziców. Zobowiązuje do tego art. 9 Konwencji, który postanawia: „Państwa-Strony zapewniają, aby dziecko nie zostało odłączone od swoich rodziców wbrew ich woli, chyba że właściwe władze - podlegające nadzorowi sądowemu - zadecydują, zgodnie z obowiązującym prawem oraz procedurą, że odłączenie

${ }^{31}$ Por. J. Izdebska, Dziecko w rodzinie u progu XXI wieku. Niepokoje i nadzieje, Białystok 2000, s. 185.

32 Prawa rodziny - prawa $w$ rodzinie, s. 57.

${ }_{33}$ Tamże, s. 59. 
takie jest konieczne ze względu na nadrzędny interes dziecka [...]"34. Istnieje zatem możliwość limitacji tego prawa, lecz tylko ze względu na zagrożenie nadrzędnego interesu dziecka, co może się zdarzyć na przykład w rodzinach dysfunkcyjnych ${ }^{35}$. Ponadto Konwencja Praw Dziecka, bardzo wyraźnie podkreślając pierwszorzędną i wspólną odpowiedzialność dwojga rodziców za wychowanie ich dzieci, w art. 18 ust. 1 postanawia: „Państwa-Strony podejmą wszelkie możliwe starania w celu zapewnienia uznania zasady, że oboje rodzice ponoszą wspólną odpowiedzialność za wychowanie dziecka. Na rodzicach lub - w odpowiednich przypadkach - na opiekunach prawnych spoczywa pierwszorzędna odpowiedzialność za wychowanie i rozwój dziecka. Winni oni kierować się przede wszystkim nadrzędnym interesem dziecka" ${ }^{36}$. Natomiast gdyby dziecko z jakichś powodów zostało oddzielone od swoich rodziców, to zgodnie z Konwencją powinno mieć możliwość kontaktu z nimi. Potwierdza to norma art. 37 lit. c Konwencji, która reguluje to prawo w kontekście ewentualnego pozbawienia dziecka wolności: „W szczególności, każde dziecko pozbawione wolności [...] - z wyłączeniem okoliczności wyjątkowych - ma prawo do pozostawania w kontakcie ze swoją rodziną poprzez korespondencję i wizyty" ${ }^{37}$.

Jeśli chodzi o prawno-naturalne podejście do rodziny jako środowiska wychowawczego przez europejski system ochrony praw człowieka Rady Europy, to trzeba stwierdzić, że jest on dość ubogi w relacji do porządku uniwersalnego ${ }^{38}$. Europejska Konwencja Praw Człowieka, z dnia 4 listopada 1950 roku, zaledwie wspomina w art. 8 ust. 1, że: „Każda osoba ma prawo do poszanowania swojego życia prywatnego i rodzinnego [...]"39, nie podając explicite przesłanek, na jakich opiera się to prawo. Konwencja w art. 8 ust. 2 zabrania jedynie co do zasady ingerencji władzy publicznej w korzystanie z tego prawa ${ }^{40}$. Dopiero I Protokół do Europejskiej Konwencji Praw Człowieka, z dnia 20 marca 1952 roku, w kontekście prawa do nauki, w art. 2

34 Tamże, s. 60.

35 Zob. J. Formański, Psychologia środowiskowa, Warszawa 2004, s. 96-102; S. Kawula, J. Brągiel, A. W. Janke, Pedagogika rodziny. Obszary i panorama problematyki. Toruń 1998, s. 131-132.

36 Prawa rodziny - prawa w rodzinie, s. 64.

37 Tamże, s. 73.

38 Warto podkreślić, że państwa europejskie są także stronami konwencji należących do uniwersalnego systemu ochrony praw człowieka, a ponadto deklarują ochronę praw rodziny, włączając w to prawo rodziców do wychowania ich dzieci zgonie ze swoimi przekonaniami filozoficznymi, moralnymi i religijnymi w swoich konstytucjach. Zob. W. Osiatyński, Prawa człowieka i ich granice, Kraków 2011, s. 79.

39 Prawa rodziny - prawa $w$ rodzinie, s. 146.

40 Zob. tamże. 
postanawia: „W wykonywaniu wszelkich funkcji w dziedzinie wychowania i nauczania, Państwo będzie szanowało prawa rodziców do zapewnienia takiego wychowania i nauczania, zgodnie z ich własnymi przekonaniami religijnymi i filozoficznymi" ${ }^{41}$. Nieco szersze unormowanie problemu, wraz z odwołaniem się do racji prawno-naturalnych, zawiera Europejska Karta Socjalna z dnia 18 października 1961 roku, zrewidowana dnia 3 maja 1996 roku. W art. 16 Europejska Karta Socjalna postanawia: „W celu zapewnienia warunków koniecznych dla pełnego rozwoju rodziny, która stanowi podstawową komórkę społeczeństwa, Strony zobowiązują się popierać gospodarczą, prawną i socjalną ochronę życia rodzinnego, takimi środkami, jak zasiłki socjalne i rodzinne, ulgi podatkowe, zabezpieczenie budownictwa rodzinnego, zasiłki dla nowożeńców oraz inne właściwe środki" ${ }^{\prime \prime 2}$. Dodatek do zrewidowanej Europejskiej Karty Socjalnej zapewnia, że ochrona z art. 16 obejmuje również rodziny osób samotnie wychowujących dziecił ${ }^{43}$.

Jeszcze bardziej ubogi pod kątem naszej analizy jest europejski system ochrony praw człowieka Unii Europejskiej. Karta Praw Podstawowych Unii Europejskiej, z dnia 7 grudnia 2000 roku, w preambule stwierdza zaledwie, że: „Świadoma swego duchowo-religijnego i moralnego dziedzictwa, Unia jest zbudowana na niepodzielnych, powszechnych wartościach godności ludzkiej, wolności, równości i solidarności; opiera się na zasadach demokracji i państwa prawnego. Poprzez ustanowienie obywatelstwa Unii oraz stworzenie przestrzeni wolności, bezpieczeństwa i sprawiedliwości stawia jednostkę w centrum swych działań" ${ }^{44}$. Unia Europejska zatem stawia na samym szczycie hierarchii wartości jednostkę, potwierdzając jej przyrodzoną i niezbywalną godność ludzką. Doktryna praw człowieka zauważa, że: „Istotą europejskiego podejścia do praw człowieka [...] jest indywidualne traktowanie uprawnień i wolności jednostki, postrzeganie jej w sposób autonomiczny, niezależnie od przynależności do konkretnej grupy społecznej”45. W konsekwencji art. 7 Karty potwierdza, że: „Każdy ma prawo do poszanowania swego życia prywatnego i rodzinnego [...]"46. Ponadto Unia Europejska w art. 24 ust. 3 Karty uznaje, że: „Każde dziecko ma prawo do utrzymywania stałego, osobistego związku i bezpośredniego kontaktu z obojgiem

${ }^{41}$ Tamże, s. 147.

${ }^{42}$ Tamże, s. 160.

${ }^{43}$ Zob. tamże, s. 163.

${ }^{44}$ Międzynarodowa ochrona praw człowieka. Wybór źródet, oprac. M. Balcerzak, Toruń 2007, s. III/1/2.

${ }^{45}$ G. Michałowska, Ochrona praw człowieka $w$ Radzie Europy $i$ w Unii Europejskiej, Warszawa 2007, s. 21.

${ }^{46}$ Międzynarodowa ochrona, s. III/1/3. 
rodziców, chyba że jest to sprzeczne z jego interesami" ${ }^{47}$. Natomiast w dziedzinie praw ekonomicznych i społecznych Karta Praw Podstawowych Unii Europejskiej w art. 33 ust. 1 gwarantuje, że: „Rodzina korzysta z ochrony pranej, ekonomicznej i społecznej" ${ }^{48}$. W tym zakresie zaś art. 33 ust. 2 Karty głosi: „W celu pogodzenia życia rodzinnego z zawodowym każdy ma prawo do ochrony przed zwolnieniem z pracy z powodów związanych z macierzyństwem i prawo do płatnego urlopu macierzyńskiego oraz do urlopu wychowawczego po urodzeniu lub adopcji dziecka"49.

Po przedstawieniu międzynarodowych standardów ochrony praw człowieka $\mathrm{w}$ ich odniesieniu do rodziny i procesu wychowawczego, który z natury w niej przebiega, należy w końcu zanalizować ogólne gwarancje, jakie daje polski system prawny we wskazanym zakresie. Konstytucja Rzeczypospolitej Polskiej, jako ustawa zasadnicza, w art. 18 w sposób ogólny postanawia: „Małżeństwo jako związek kobiety i mężczyzny, rodzina, macierzyństwo i rodzicielstwo znajdują się pod ochroną i opieką Rzeczypospolitej Polskiej"s0. Zatem rodzina, oparta na małżeństwie kobiety i mężczyzny, jest samoistną wartością chronioną przez polskiego ustawodawcę. Ustawa zasadnicza, co prawda, nie podaje motywów tej ochrony, jednak takie wartości chronione jak macierzyństwo i rodzicielstwo dają podstawę, aby sądzić, że jednym z motywów udzielenia formalno-prawnej ochrony rodzinie przez polskiego ustawodawcę jest proces wychowawczy, jaki z natury przebiega w rodzinie. W tym kontekście macierzyństwo i rodzicielstwo, czyli - w przypadku rodzicielstwa - macierzyństwo i ojcostwo razem wzięte, nie mogą być pojmowane wyłącznie na poziomie fizycznym, gdyż zarówno macierzyństwo, jak i ojcostwo realizują się jeszcze bardziej na poziomie więzi emocjonalno-ekspresywnych, jakie kształtują się między rodzicami i ich dziećmis' ${ }^{51}$. Więzi te również ex natura rei przynaglają rodziców do wychowania swego potomstwa. Jeśli chodzi o wychowanie dzieci, to art. 48 ust. 1 Konstytucji RP explicite gwarantuje, że: „Rodzice mają prawo do wychowania dzieci zgodnie z własnymi przekonaniami [... $]^{\prime 52}$. Podobnie art. 53 ust. 3 Konstytucji RP potwierdza: „Rodzice mają prawo do zapewnienia dzieciom wychowania i nauczania moralnego i religijnego zgodnie ze swoimi przekonaniami [... $]^{\prime 53}$. Ustawodawca polski zatem uznaje i chroni naturalne prawo rodziców

\footnotetext{
47 Tamże, s. III/1/5.

48 Tamże.

49 Tamże, s. III/1/6.

50 Dz.U. 1997, nr 78, poz. 483.

51 Zob. J. Ignatowicz, M. Nazar, Prawo Rodzinne, Warszawa 2006, s. 48.

52 Dz.U. 1997, nr 78, poz. 483.

53 Tamże.
} 
do wychowania ich dzieci zgodnie z przekonaniami rodziców, w szczególności moralnymi i religijnymi. Art. 53 ust. 3 Konstytucji RP zapewnia również, że to prawo rodziców w zakresie wychowania i nauczania moralnego i religijnego będzie chronione na poziomie edukacyjno-wychowawczym, który jak wiadomo - w dużej części przebiega poza rodziną, czyli w instytucjach edukacyjno-wychowawczych. Z teoretyczno-prawnego punktu widzenia nie jest zatem możliwe, aby publiczne instytucje oświatowo-wychowawcze odmawiały rodzicom poszanowania powyżej wskazanego prawa, przynajmniej w sferze moralno-religijnej, gdyż to właśnie rodzina - jako jedyna instytucja życia społecznego i państwowego - jest pierwotnym i podstawowym środowiskiem wychowawczym. Warto także dodać, iż art. 71 ust. 1 Konstytucji RP gwarantuje, że: „Państwo w swojej polityce społecznej i gospodarczej uwzględnia dobro rodziny [...]" ${ }^{54}$. Wydaje się zatem, że przepis ten można także aplikować do przebiegu procesu wychowawczego w rodzinie, który w szczególnie trudnych sytuacjach społeczno-gospodarczych rodziny pozwala jej korzystać z pomocy państwa z pełnym poszanowaniem integralności tak zwanej rodziny małej, składającej się z rodziców i ich dzieci.

Powyższe teoretyczno-prawne rozważania o wychowaniu w rodzinie warto podsumować słowami papieża Jana Pawła II, który nie tylko na gruncie stricte teologicznym, ale także na gruncie etycznym i prawno-naturalnym bronił praw rodziny, włącznie z jej prawem do wychowania swego potomstwa. Jan Paweł II, w przemówieniu do ruchów obrony życia w dniu 15 listopada 1991 roku, podkreślił, że:

Po byciu przyjętym, dziecko podlega wychowaniu, opiece i pobudzaniu do pełnego swego rozwoju, w ten sposób, że może osiągnąć należną dojrzałość ludzką. Człowiek bowiem nie potrafi nawet zrozumieć kim jest, a co gorsza staje się dla siebie samego nierozwiązywalną tajemnicą, jeśli nie nauczy się kochać i nie czuje się kochanym. Wymaga się zatem zaangażowania wszystkich na rzecz ekologii ludzkiej, czyli w celu stworzenia, ze współpracą wszystkich, przyjaznego środowiska dla osoby i jej rozwoju [...]. Pierwszą i niezastąpioną strukturą zdolną do tego jest z pewnością rodzina: w niej człowiek doświadcza pierwszych, determinujących go doświadczeń i otrzymuje pierwsze i najważniejsze nauczanie o prawdzie i dobru, uczy się co znaczy kochać i być kochanym $^{55}$.

54 Tamże.

55 Jan Paweł II, Przemówienie do ruchów obrony życia z dnia 15 listopada 1991 roku, w: R. García de Haro, C. Rossi Espagnet, Matrimonio e famiglia nei documenti del magistero. Corso di teologia matrimoniale, Milano 2000, s. 354. 
Zatem rodzina jest historycznie pierwotną i teoretycznie niezastąpioną strukturą, w której przebiega integralny rozwój każdego dziecka. Ten rozwój - jak wykazaliśmy - z natury dokonuje się w procesie wychowawczym w środowisku rodzinnym, które jest największym bogactwem człowieka ${ }^{56}$. Rodzina ma więc prawno-naturalną zdolność do zapewnienia dzieciom optymalnego rozwoju osobowego, choć w wypełnianiu tego zadania, zwłaszcza w dzisiejszych czasach, potrzebuje pomocy państwa. Niektóre bowiem zadania edukacyjno-wychowawcze przekraczają możliwości rodziny.

\section{Rola państwa w procesie wychowania}

Jak stwierdziliśmy powyżej, zarówno dokumenty prawa międzynarodowego ochrony praw człowieka, jak i Konstytucja RP w sposób bezsporny uznają rodzinę za pierwotne i zasadnicze środowisko wychowawcze. A contrario państwo nie może zająć miejsca rodziny w procesie wychowawczym, dlatego wspomniane źródła prawa pozytywnego przyznają państwu zaledwie pewne uprawnienia w tej sferze, jednocześnie nakładając na jego organy szereg obowiązków względem rodziny, włącznie z fundamentalnym obowiązkiem poszanowania niezbywalnych praw rodziców względem ich dzieci w zakresie wychowania. Zanim jednak przejdziemy do pozytywnego przedstawienia obowiązków i praw państwa w zakresie wychowania, rozpoczniemy naszą refleksję od przytoczenia określenia państwa i jego funkcji względem osoby, aby w ten sposób lepiej zrozumieć rolę państwa w relacji do rodziny.

W naukach o państwie, prawie i polityce powszechnie przyjmuje się za prof. Jerzym Jellinkiem - najbardziej ogólną, trójelementową definicję państwa, według której: „Państwo to trwały związek ludzi stale zamieszkujących określone terytorium, podlegających władzy zwierzchniej” ${ }^{57}$. Jak łatwo zauważyć, definicja ta ujmuje ludność jako główny podmiot tworzący państwo, stawiając na dalszym jego planie terytorium i władzę. Ujęcie to współgra ze współczesnym rozumieniem państwa demokratycznego, w którym podmiotem władzy jest lud, czasami utożsamiany z narodem. Zatem zasada suwerenności ludu wiąże się nie tylko z prawem każdego ludu-narodu do zorganizowania się w samodzielne państwo, ale także zakłada priorytet

${ }^{56}$ Zob. R. García de Haro, C. Rossi Espagnet, dz. cyt., s. 354.

57 B. Szmulik, M. Żmigrodzki, Pojęcie, sposoby definiowania oraz cechy państwa, w: B. Szmulik, M. Żmigrodzki (red.), Wprowadzenie do nauki o państwie i polityce, Lublin 2010, s. 16. Zob. J. Jellinek, Ogólna nauka o państwie, t. II, Warszawa 1924, s. 50. 
ludu-narodu wobec państwa ${ }^{58}$. Zatem: „Państwo działa w ramach społeczeństwa, a społeczeństwo «posługuje się» państwem, by osiągnąc cele zbiorowe, do których jest niezbędna zorganizowana władza publiczna" ${ }^{59}$. Na bazie powyższych przesłanek należy wyciągnąć ogólny wniosek co do procesu wychowania, a mianowicie władza państwowa, rozumiana jako organy państwa i zarazem nie będąca pierwotnym i zasadniczym środowiskiem wychowawczym, nie może ignorować głosu rodziców co do istotnych elementów wychowania ich dzieci, ponieważ rodzice, współtworzący zbiorowy podmiot suwerenności państwa, powinni niejako „posługiwać się” państwem w celu lepszego wychowania swoich dzieci. W konsekwencji państwo, poprzez swoje organy, powinno oddać się na służbę rodzicom w procesie wychowania ich dzieci, zwłaszcza w tych jego dziedzinach i obszarach, gdzie dobro dzieci przekracza możliwości ich rodziców ${ }^{60}$. Każde zatem działanie państwa naruszające prawno-naturalną legitymację rodziców do wychowania dzieci zgodnie z ich własnymi przekonaniami, a w konsekwencji także ogólną zasadę suwerenności zbiorowego podmiotu państwa, jakim jest ludnaród, jest poważnym wykroczeniem przez organy państwowe poza swoje kompetencje, a także nadużyciem przez nie demokratycznie powierzonej im władzy.

W celu pozytywnego określenia szczegółowych obowiązków państwa w procesie wychowawczym pomocne będzie także przytoczenie ogólnych funkcji państwa. Włoski uczony C. Mozzarelli definiuje je następująco:

Funkcje, które wykonuje państwo za pomocą władzy zwierzchniej, są w istocie dwie: a) wydawanie norm mających za cel wzbudzanie w obywatelach zachowań, które są uważane za korzystne dla wspólnoty, lub eliminowanie zachowań uważanych za szkodliwe, czyli funkcja prawodawcza; b) tworzenie usług wspólnotowych czyli publicznych, których piastujący władzę nie uważają za słuszne zawierzyć wolnej inicjatywie prywatnej, czyli funkcja zarządzania. Wśród tych usług, jedna z najbardziej podstawowych i pierwotnych w porządku chronologicznym to strzeżenie sprawiedliwości, która często jest uważana za trzecią funkcję, osobną od dwóch wcześniej wymienionych ${ }^{61}$.

58 Zob. E. Kustra, Wstęp do nauk o państwie i prawie, Toruń 1997, s. 25.

59 Tamże, s. 26.

${ }^{60}$ Zob. A. Zwoliński, Państwo, w: E. Gigilewicz (red.), Encyklopedia Katolicka, t. XIV, Lublin 2010, s. 1250.

${ }^{61}$ C. Mozzarelli, Stato. Il potere. Lo stato moderno, w: G. Armani (red.), Enciclopedia del Diritto, Borgaro Torinese 2001, s. 1263. 
Syntetyzując to ujęcie i aplikując je do procesu wychowawczego, należy skonstatować, że państwo w dziedzinie wychowania ma trzy istotne funkcje: funkcję prawodawczą, funkcję administracyjną i funkcję sądowniczą.

Jeśli chodzi o pierwszą z nich, to państwo poprzez swoje konstytucyjne organy ma poważny obowiązek stanowienia takich źródeł powszechnie obowiązującego prawa, które - z jednej strony - zabezpieczyłyby pierwotne i podstawowe prawo rodziców do wychowania swoich dzieci zgodnie $\mathrm{z}$ ich własnymi przekonaniami, włączając $\mathrm{w}$ nie przede wszystkim przekonania moralne i religijne, a - z drugiej strony - które by zabezpieczyły dzieciom i młodzieży prawo „dostępu do dóbr kultury, będącej źródłem tożsamości narodu polskiego, jego trwania i rozwoju" ${ }^{2}$. Trzeba koniecznie pamiętać, że wskazane prawa, zarówno rodziców, jak i ich dzieci, w dzisiejszym wysoko zindustrializowanym i zinformatyzowanym społeczeństwie niewątpliwie przekraczają zarówno kulturowe, jak i ekonomiczne możliwości przeciętnej rodziny. W tym zakresie państwo, realizując swoją funkcję prawodawczą w sferze wychowania, powinno zadbać o wydanie przepisów prawnych zwłaszcza w następujących materiach regulacji: 1) możliwość swobodnego wyboru szkół i innych ośrodków wychowania dla dzieci przez ich rodziców, w tym szkół o charakterze wyznaniowym, a przypadku wyboru szkół państwowych możliwość wpływania przez rodziców na kierunki wychowania w zakresie wyznawanej przez nich moralności i religii; 2) możliwość przynajmniej częściowego dofinansowania edukacji w przypadku wyboru przez rodziców dla swoich dzieci szkół innych niż państwowe; 3) kompleksowe i szczegółowe określenie organizacji szkolnictwa w państwie, uwzględniające przy tym wszystkie poziomy edukacji; 4) zabezpieczenie dostępności ofert edukacyjno-wychowawczych dla dzieci i młodzieży szczególnej troski, a zwłaszcza dla osób niepełnosprawnych fizycznie i umysłowo, dzieci z rodzin patologicznych, a także dla nieletnich sprawców wykroczeń i przestępstw; 5) określenie źródeł i kryteriów finansowania wszystkich typów placówek i ośrodków wychowawczych; 6) oznaczenie dolnego i górnego wieku dziecka, w którym jest ono zobowiązane do spełniania obowiązku szkolnego; 7) określenie poziomu edukacji odpowiadającego współczesnym standardom, między innymi poprzez przyjęcie odpowiednich programów edukacyjno-wychowawczych i zagwarantowanie odpowiednich środków technicznych w edukacji; 8) oznaczanie kwalifikacji i kompetencji nauczycieli i pedagogów; 9) zdefiniowanie ram obowiązku współpracy organów szkoły oraz nauczycieli i pedagogów z rodzicami w duchu poszanowania przekonań moralnych i religijnych rodziców; 10) troska o zdrowie fizyczne i psychiczne wychowanków, włącznie z określeniem prewencyjnych progra-

${ }^{62}$ Art. 6 Konstytucji RP. 
mów edukacyjno-wychowawczych w zakresie zwalczania narkomanii, alkoholizmu i innych zagrożeń; 11) określenie prawnych ram opieki zastępczej w przypadkach gdy byłoby to konieczne ${ }^{63}$.

Jeśli chodzi o funkcję administracyjną w odniesieniu do procesu wychowania, to państwo jest zobowiązane tak zarządzać sprawami edukacyjnoopiekuńczymi za pomocą zarówno pionu administracji rządowej, jak i pionu administracji samorządowej, aby przede wszystkim poszanować legitymację prawno-naturalną rodziców do wychowania ich dzieci. Dlatego działania administracji publicznej nie mogą być sprzeczne z uznanymi przez Polskę, w wiążących ją źródłach prawa międzynarodowego ${ }^{64} \mathrm{i}$ w powszechnie obowiązujących źródłach prawa wewnętrznego ${ }^{65}$, przyrodzonymi prawami rodziców w zakresie wychowania, a w szczególności w zakresie wychowania moralnego i religijnego. Nieposzanowanie przez administrację publiczną zasady autonomii rodziny w powyższych dziedzinach ${ }^{66} \mathrm{i}$ nakładanie $\mathrm{w}$ tym zakresie na rodzinę nadmiernych ciężarów, zwłaszcza biurokratycznych i finansowych, jest de facto zaprzeczeniem zobowiązań przyjętych przez państwo Polskie. Administracja bowiem, służąc dobru powszechnemu i kierując się dobrem rodziny ${ }^{67}$, powinna zapewnić wykonywanie wszelkich naturalnych praw rodziców, tym bardziej że zostały one potwierdzone i zagwarantowane przez Polskę w jej prawie pozytywnym. Jest zatem oczywiste, że administracja publiczna w tym względzie nie może działać według zasady uznaniowości, ale jest związana konstytucyjną zasadą legalności, według której: "Organy władzy publicznej działają na podstawie i w granicach prawa"68. Organy administracji publicznej, będąc związane dyspozycjami przepisów prawnych, które - jak wykazaliśmy powyżej - bezwzględnie uznają rodzinę za pierwotne i zasadnicze środowisko wychowawcze, są zatem zobowiązane do wykonywania norm zawartych w źródłach powszechnie obowiązującego prawa $^{69}$, czyli do działania w sytuacjach i formach ściśle określonych $\mathrm{w}$ tych przepisach. Te zaś ewidentnie dają rodzinie pozycję nadrzędną i autonomiczną $\mathrm{w}$ procesie wychowawczym.

${ }^{63}$ Zob. A. Mazan, Wychowanie. Kompetencja państwa, w: E. Ozorowski (red.), dz. cyt., s. 478.

${ }^{64}$ Zob. art. 9 Konstytucji RP.

${ }^{65}$ Zob. art. 87 ust. 1 Konstytucji RP.

${ }^{66}$ Zob. A. Krajewska, Prawo $i$ wychowanie $w$ rodzinie $w$ nauczaniu Jana Pawła II, w: R. Sztychmiler (red.), Jan Pawet II prawodawca i stuga prawa Bożego, Olsztyn 2006, s. 210.

${ }^{67}$ Zob. art. 71 ust. 1 Konstytucji RP.

${ }^{68}$ Art. 7 Konstytucji RP.

${ }^{69}$ Por. art. 87 ust. 1 Konstytucji RP. 
Jeśli chodzi o funkcję sądowniczą państwa w odniesieniu do procesu wychowawczego, to polega ona na wykonywaniu zadań państwowych, mających na celu orzekanie w sprawach rodzinnych i opiekuńczych. W niektórych bowiem sytuacjach, zwłaszcza gdy doszłoby do całkowitego zaniku więzi rodzinnych, do eskalacji patologii życia rodzinnego lub do działań rodziców, które godziłyby w porządek prawny państwa ${ }^{70}$, interwencja sądu rodzinnego lub opiekuńczego staje się konieczna dla zabezpieczenia dobra dziecka, a w niektórych przypadkach także dobra rodziny lub dobra publicznego ${ }^{71}$. Jest jednak oczywiste, że sądy rodzinne i opiekuńcze nie mogą wypełniać tego obowiązku w sposób arbitralny, pozbawiając pierwszeństwa rodziców w wychowaniu ich dzieci, a tym samym przekreślając zasadę autonomii rodziny ${ }^{72}$. Zatem sądy rodzinne i opiekuńcze muszą ograniczyć swoje orzekanie w sprawach związanych z procesem wychowawczym do niezbędnego minimum spraw, które zostały ściśle określone przez polskiego ustawodawcę. Tymi sprawami są: 1) sprawy o rozwód, separację lub w rzadkich przypadkach - o unieważnienie małżeństwa, w których sąd ma obowiązek postanowić, kto będzie wykonywać władzę rodzicielską, a także kto i w jakim zakresie będzie zobowiązany do alimentacji dziecka; 2) sprawy o pozbawienie, zawieszenie lub ograniczenie władzy rodzicielskiej nad dzieckiem; 3) sprawy o całkowite ubezwłasnowolnienie małoletniego; 4) sprawy o przysposobienie małoletniego lub rozwiązanie przysposobienia; 5) sprawy o umieszczenie małoletniego w rodzinie zastępczej lub w placówce opiekuńczo-wychowawczej; 6) sprawy o ustanowienie dla małoletniego opieki lub kurateli; 7) sprawy karne lub mieszane dotyczące małoletnich ${ }^{73}$.

Przeprowadzenie tych spraw przy wystąpieniu okoliczności przewidzianych przez ustawodawcę w ustawach, realizowane przez sądy rodzinne i opiekuńcze, jest szczególnym obowiązkiem państwa i służy zagwarantowaniu dziecku środowiska wychowawczo-opiekuńczego, a w nim realizowania minimalnych standardów integralnego rozwoju osobowego. W wypełnianiu tego zadania państwo jako takie nie staje się stricte środowiskiem wychowawczym, gdyż brakuje mu naturalnej zdolności ku temu. Jednakże państwo, ze względu na swój potencjał kulturowo-ekonomiczny, pełni w procesie wychowawczym dwie funkcje: 1) funkcję pomocnicą względem ro-

${ }^{70}$ Zob. J. Ignatowicz, M. Nazar, dz. cyt., s. 49.

${ }^{71}$ A. Mazan w tym zakresie wyraża pogląd, że: „Zasada interwencji polega na prawie do zastąpienia działań wychowawczych rodziców przez osoby trzecie w sytuacji, gdy wychowanie dzieci jest uniemożliwione. Pozwala ona, w skrajnym przypadku, na pozbawienie władzy rodzicielskiej na mocy wyroku sądowego". A. Mazan, dz. cyt., s. 478.

72 Zob. J. Ignatowicz, M. Nazar, dz. cyt., s. 49.

${ }^{73}$ Zob. T. Smyczyński, dz. cyt., s. 20-21. 
dziny, rozumianej jako pierwotne i zasadnicze środowisko wychowawcze ${ }^{74}$; 2) funkcję służebną w relacji do dzieci, które są zagrożone utratą naturalnego środowiska wychowawczego przez całkowity jego brak lub przez poważną jego dysfunkcję. Państwo bowiem ma podstawowy obowiązek niesienia pomocy każdemu obywatelowi, a w szczególny sposób dziecku, w osiągnięciu nadrzędnego celu, jakim jest ukształtowanie człowieczeństwa w procesie wychowawczym ${ }^{75}$.

\section{Wnioski końcowe}

W świetle powyższych ustaleń należy bezspornie skonstatować, że pierwotnym i zasadniczym środowiskiem wychowawczym jest rodzina. Tylko rodzice mają prawno-naturalną legitymację do wychowania zrodzonych przez siebie dzieci zgodnie ze swoimi przekonaniami, a w szczególności zgodnie ze swymi przekonaniami moralnymi i religijnymi. Państwo natomiast, jako byt społeczny skierowany do udzielania pomocy w osiągnięciu celów przewyższających możliwości poszczególnych rodzin, w procesie wychowania powinno spełniać jedynie funkcję pomocniczą w relacji do zadań wychowawczych rodziców ${ }^{76}$, w pełni szanując prawno-naturalną autonomię rodziny. Standard ten, jak zdołaliśmy wykazać, został powszechnie przyjęty wśród współcześnie istniejących państw ${ }^{77}$, które uznały rodzinę za pierwotne i podstawowe środowisko wychowawcze, akceptując również subsydiarną rolę państwa w tym zakresie.

Dla bardziej ścisłego określenia powyżej wskazanych proporcji w procesie wychowania posłużymy się słowami papieża Jana Pawła II z Listu do Rodzin z dnia 2 lutego 1994 roku, które - opierając się nie tylko na przesłankach objawionych, lecz przede wszystkim na prawie natury - są trafną rekapitulacją naszego przedłożenia, a z drugiej strony zawierają w sobie autorytatywny potencjał chrześcijańsko-pedagogiczny. Jan Paweł II konstatuje:

74 A. Mazan w tym zakresie wyraża pogląd, że: „Zasada pomocniczości polega na tym, że państwo powinno zapewnić ochronę obowiązków i praw rodziców oraz osób mających udział w wychowaniu, a także pomagać rodzicom wszędzie tam, gdzie ich bezpośrednia lub pośrednia inicjatywa może być wzmocniona. W przypadku jej braku państwo może podejmować inicjatywę, ale powinno uwzględnić życzenia rodziców”. A. Mazan, dz. cyt., s. 478.

75 Zob. tamże; R. Sztychmiler, Rodzina i prawo, w: W. Nowak, M. Tunkiewicz (red.), Godność człowieka i rodziny, Olsztyn 2007, s. 146.

76 Por. preambuła Konstytucji RP.

77 Standard, o którym mowa, uznało około 165 państw na 194 państwa współcześnie istniejące. Por. http://pl.wikipedia.org/wiki/Pa\%C5\%84stwa_\%C5\%9Bwiata, dnia 6.11.2011 r. 
Bezpośrednimi wychowawcami w stosunku do swoich dzieci pozostają zawsze na pierwszym miejscu rodzice. Rodzice mają też w tej dziedzinie pierwsze i podstawowe uprawnienia. Są wychowawcami, ponieważ są rodzicami. Jeśli zadanie to rodzice z kolei dzielą z innymi ludźmi, a także z instytucjami, na przykład [...] z państwem, to zawiera się w tym prawidłowe odzwierciedlenie zasady pomocniczości. [...] W tych dziedzinach, gdzie rodzina nie może skutecznie działać sama, zasada pomocniczości wspiera miłość rodzicielską, odpowiada dobru rodziny. Pomocniczość dopełnia w ten sposób miłość rodzicielską, a równocześnie potwierdza jej fundamentalny charakter. Wszyscy inni uczestnicy procesu wychowawczego działają poniekąd w imieniu rodziców, w oparciu o ich zgodę, a w pewnej mierze nawet ich zlecenie (LdR 16).

Harmonijna współpraca państwa z rodzicami, wraz z poszanowaniem prawno-naturalnej autonomii rodziców w zakresie wychowania ich dzieci, jest właściwym sposobem kształtowania dojrzałej osobowości młodego człowieka.

\section{Family Education or State Education? Theoretical and Legal Reflections (Summary)}

The author, in the perspective of the eternal law of nature and the contemporary protection of human rights, tries to find the answer to the question concerning the educational environment of a human being and the entities which are responsible for making this process successful. In order to do this, the author first analyzes the nature of education by defining the semantic substance of this concept as shaping of a human being's humanity, that is forming and improving one's integral and healthy personality. He then analyzes education in a family and concludes that the family is historically the prime and theoretically an irreplaceable structure for the integral development of each child, and has been accepted by the vast majority of modern states in the international agreements concerning the protection of human rights. Therefore, it is the family that has the legitimacy for children's education, particularly when it comes to moral and religious education. Finally, the author reflects on the role of the state in the process of education. He emphasizes that the state, in accordance with the principle of democracy, should serve both the family and the individual, in order to secure those goods which exceed their capabilities. To this end, the state should help the family achieve its natural educational objective by providing good legislation and proper administration, particularly at the level of school education. However, when a generative family is not present or it is a seriously dysfunctional one, the state should secure a substitute educational environment for children by taking legal action. 